\title{
Konvergensi Setengah Hati : Invasi Konten Media Sosial dalam Program Berita Televisi di TVOne
}

\author{
Vivin Lizetha, S. IP ${ }^{1}$, Angga Prawadika, S. IP, M.A ${ }^{2}$ \\ ${ }^{1,2}$ Faculty of Social Sciences and Political Sciences Airlangga University, Surabaya, Indonesia. \\ Email:vivin.lizetha@gmail.com
}

\begin{abstract}
Technological growth provides a big impact to both development and changes in the mass media landscape. Even though broadcast media like radio and television still have a place in the heart of loyal audiences, it can't be denied that the existence of social media has a significant impact on media development. Mainstream media, especially television broadcasters, are starting to look for alternative ways to maintain their dwindling audience. One of this strategy is by integrating social media content into television programs. This particular strategy is easily identified with television programs. No exception in the news program on TVOne. It is interesting to observe how television news programs use social media content to survive in the midst of the social media onslaught on conventional mass media like television or radio. This research focuses on news programs on TVOne that take social media content into the show. We will use descriptive qualitative research using the case study method and use the political economy theory of the media.
\end{abstract}

Keywords: new media; share and rating; mainstream media; television programs

\begin{abstract}
Pertumbuhan teknologi memberi dampak besar bagi perkembangan dan perubahan media massa. Saat ini, meskipun media penyiaran seperti radio dan televisi masih memiliki tempat di hati audiens, namun harus diakui bahwa keberadaan media sosial memberikan dampak yang signifikan dalam perkembangan media. Media arus utama, khususnya media penyiaran televisi mulai mencari cara agar tidak ditinggalkan oleh audiensnya. Mereka mulai memasukkan konten media sosial ke dalam program televisi. Hal itu terjadi di semua tayangan dalam program televisi di Indonesia. Konten media sosial menjadi pelengkap atau bahkan menjadi tayangan utama program televisi. Tidak terkecuali pada televisi nasional berita 24 jam, TVOne.Oleh karena itu, menarik untuk diteliti bagaimana perpindahan konten media sosial ke program berita televisi menjadi jalan bagi TVOne untuk menaikkan share dan rating serta bertahan di tengah gempuran media sosial. Penelitian ini berfokus pada program di TVOne yang mengambil konten media sosial ke dalam tayangannya. Peneliti akan menggunakan penelitian deskriptif kualitatif menggunakan metode studi kasus dan menggunakan teori ekonomi politik media.
\end{abstract}

Kata kunci : Media baru; Share and Rating; Media arus utama; Program televisi

\section{A. PENDAHULUAN}

Studi mengenai efek perkembangan media baru terhadap proses kerja media massa konvensional di Indonesia masih terbilang minim walaupun perubahan sosio-politik Indonesia modern sangat dipengaruhi oleh perubahan lanskap media (Sen \& Hill, 2006). Riset mengenai dinamika antara industri media massa konvensional dengan perkembangan media umumnya berpusat pada proses konvergensi industri media regional (Wilson, 2000) maupun analisis pada 
pola industri yang berubah akibat disrupsi teknologi internet pada mekanisme industri standar yang sebelumnya dilanggengkan oleh industri media massa (Sapiro \& Soss, 2010). Studi mengenai konvergensi media sebenarnya merupakan sebuah isu yang telah lama kehilangan pamor di negara-negara maju seiring dengan bergesernya arah fokus riset ke bentuk industri media yang semakin terintegrasi dan terikat dengan teknologi komunikasi dan informasi (Murschetz, 2015). Sayangnya dinamika industri media massa konvensional di Indonesia memiliki konteks historis, ekonomi, serta sosial-politik yang berbeda (Maxwell \& Miller, 2011) sehingga membutuhkan pembacaan yang lebih mendalam. Studi ini merupakan upaya untuk menyediakan sebuah analisis studi kasus yang lebih mendalam pada proses pengembangan program berita di televisi swasta Indonesia seiring dengan kehadiran konten-konten media sosial yang pada saat yang sama juga menawarkan informasi pada khalayak. Analisis studi kasus dianggap tepat untuk melihat berbagai aspek spesifik dalam kasus pengembangan berita berbasis konten internet di stasiun televisi Indonesia.

Media sosial diakui saat ini memegang posisi penting dalam mempengaruhi proses pembuatan program sebuah tayangan televisi, tak terkecuali dalam pembuatan tayangan berita. Dahulu para jurnalis mencari berita sendiri lalu mengemasnya dalam proses produksi berita kemudian menayangkan dalam sebuah tayangan acara berita (Sullivan \& Jiang, 2010). Namun saat ini tak jarang beberapa video yang sedang viral di media sosial juga dijadikan tayangan utama dalam program berita. Kondisi ini memberikan tiga isu penting berkaitan dengan posisi jurnalisme serta dinamika industri media kontemporer Indonesia. Isu pertama berkaitan dengan isu validitas berita 'viral' sebagai sebuah objek sahih dari kerja jurnalisme profesional. Isu kedua berkaitan dengan semakin menguatnya ketergantungan media massa konvensional terutama televisi untuk menggunakan konten-konten media sosial yang dianggap bebas, murah, dan menjamin perhatian khalayak. Isu ketiga merupakan efek dari perubahan kerja ruang berita stasiun televisi pada konteks sosial-politik yang lebih luas (Muchtar \& Ritchey, 2014). Studi ini berupaya untuk membantu mengurasi isu kedua dengan berupaya menganalisis latar belakang dan proses pengambilan keputusan ruang berita stasiun televisi dalam menggunakan konten media sosial.

TVOne dipilih sebagai objek utama dalam studi ini karena merupakan satu dari dua televisi nasional berita 24 jam yang ada di Indonesia. Berdiri sejak 2008, televisi milik Bakrie Group ini konsisten menayangkan berbagai informasi mulai dari peristiwa hingga politik yang terjadi di Indonesia (Tapsell, 2019). Pangsa audiens TVOne biasanya berada di angka 8 persen, lebih tinggi dibandingkan pesaingnya, Metro TV yang hanya 4 persen. Dari hasil tersebut, sebagai televisi berita 24 jam, TVOne termasuk cukup diminati audiens. Format program yang ditayangkan TVOne pun cukup beragam mulai dari program tayangan berita hingga program dokumenter. Umumnya hasil tayangan berasal dari liputan jurnalis TVOne namun seiring 
memasuki era digital beberapa video yang bersumber dari media sosial mulai digunakan. Baik itu sebagai pelengkap maupun berdiri sendiri dalam segmen sebuah tayangan berita. Kondisi ini tentu bertolak belakang dengan karakteristik dari kedua jenis media tersebut.

Televisi dengan segala macam kebutuhannya baik dari sudut pandang modal, infrastruktur komunikasi, dan kepentingan pemilik media, tidak dapat bebas dari nilai mengingat media merupakan entitas ekonomi. Pertemuan industri media dan media sosial di era digital saat ini menawarkan isu krusial berkaitan dengan bagaimana industri media konvensional beradaptasi dengan lanskap media yang kian berubah. Mengacu pada latar belakang ini peneliti ingin melihat proses produksi program di TVOne yang mengambil konten media sosial dalam tayangannya. Peneliti akan melihat proses pembuatan tayangan televisi dengan terjun langsung ke lapangan dan melihat secara alamiah bagaimana sebuah program televisi yang memutuskan untuk mengambil konten dari media sosial.

Proses adaptasi yang dilakukan stasiun televisi dapat dianalisis menggunakan teori strukturasi Anthony Giddens yang menjelaskan bahwa struktur dan agensi tidak dipandang sebagai dua hal yang terpisah, karena jika demikian akan muncul dualisme struktur-agensi (Giddens, 2006). Struktur dan agensi, menurut Giddens, harus dipandang sebagai dualitas, dua sisi mata uang yang sama. Hubungan antara keduanya bersifat dialektik, dalam arti struktur dan agensi saling mempengaruhi dan hal ini berlangsung terus menerus, tanpa henti. Struktur mempengaruhi agensi dalam dua arti: memampukan (enabling) dan menghambat (constraining). Terjadinya paradoks dalam pengertian struktur ini karena Giddens melihat struktur merupakan hasil (outcome) sekaligus sarana (medium) praktik sosial. Dan bukanlah merupakan totalitas gejala, bukan kode tersembunyi seperti dalam strukturalisme, dan bukan pula kerangka keterkaitan bagian-bagian dari suatu totalitas seperti yang dipahami para fungsionalis. Teori Giddens ini dapat dijadikan basis untuk menganalisis bagaimana industri media sebagai sebuah struktur yang sejak lama terjalin dari agensi-agensi yang berupa para pekerja jurnalis. Kehadiran media sosial menawarkan ruang bagi banyak agensi baru yang berpotensi mengubah struktur media secara keseluruhan. Dalam pengertian Giddens, agensi dapat meninggalkan struktur dan tidak selalu tunduk pada struktur. Ia dapat mencari kesempatan maupun kemungkinan untuk keluar dari peraturan dan ketentuan yang ada (Giddens, 2006). Situasi ini disebut dialectic of control.

Teori yang digunakan selanjutnya adalah teori ekonomi politik media. Ekonomi politik media terkait dengan masalah kapital atau modal dari para investor yang bergerak dalam industri media. Para pemilik modal menjadikan media sebagai usaha untuk meraih untung, dimana keuntungan tersebut diinvestasikan kembali untuk pengembangan medianya. Sehingga pengakumulasian keuntungan itu, menyebabkan kepemilikan media semakin besar. Untuk mengetahui lebih jauh tentang bagaimana media memproduksi isi, mendistribusikan sehingga 
bernilai ekonomis, Vincent Mosco menawarkan tiga konsep untuk mendekatinya yakni: komodifikasi (commodification), spasialisasi (spatialization) dan strukturasi (structuration) (Mosco, 1996:139). Teori ekonomi politik memiliki kekuatan pada tiga hal yaitu berfokus pada bagaimana media dibangun dan dikendalikan, menawarkan penyelidikan empiris mengenai keuangan media, dan mencari hubungan antara proses produksi konten media dan keuangan media (Barant, 2010:263). Industri media merupakan serangkaian perusahaan media berskala nasional yang secara jelas mengontrol pola dominasi informasi Indonesia sejak era 90an (Tapsell, 2019). Industri media terutama televisi swasta memegang kekuatan ekonomi utama dalam industri media di Indonesia mengingat televisi merupakan media massa paling populer dan dapat diakses hampir di seluruh wilayah kepulauan Indonesia (Sen \& Hill, 2006). Popularitas internet terutama media sosial pada akhir tahun akibat perkembangan infrastruktur komunikasi serta semakin terjangkaunya perangkat telekomunikasi menyebabkan posisi stasiun televisi sebagai pelaku industri media utama di Indonesia terancam secara ekonomi. Internet menawarkan beragam informasi yang sebelumnya ditawarkan secara monopolistis oleh media massa konvensional. Posisi ini memaksa stasiun televisi harus beradaptasi dengan perkembangan internet, baik dengan menghadirkan layanan televisi di ruang siber maupun mengadaptasi konten-konten media sosial pada layanan di televisi. Proses ini tidak berjalan langsung dengan mulus dengan baik dan sangat bergantung pada konteks yang ada di masing-masing negara, termasuk di Indonesia.

Menurut Barant (2010:263), para teoritikus ekonomi politik menitikberatkan pada bagaimana proses produksi konten dan distribusi dikendalikan. Kekuatan utama teori ini terletak pada kemampuannya dalam menyodorkan gagasan yang dapat dibuktikan secara empiris, yakni gagasan yang menyangkut kondisi pasar. Ekonomi politik adalah pendekatan kritik sosial yang berfokus pada hubungan antara struktur ekonomi dan dinamika industri media dan konten ideologis media. (McQuail,2011:105). Melihat hal ini maka institusi media merupakan sebagai bagian dari sistem ekonomi dengan hubungan erat kepada sistem politik. Hal ini mengakibatkan berkurangnya sumber media yang independen, konsentrasi pada khalayak yang lebih luas, menghindari risiko, dan mengurangi penanaman modal pada tugas media yang kurang menguntungkan. Pada sisi lainnya, media juga akan mengabaikan kepentingan khalayak

potensial yang kecil dan miskin, karena dinilai tidak menguntungkan. Kemudian pemberitaan terhadap kelompok masyarakat minoritas, cenderung tidak seimbang. Barant (2011:250) menyebutnya teori ekonomi politik media fokus pada penggunaan elite sosial

\section{B. METODE}

Penelitian ini adalah penelitian yang bersifat kualitatif. Penelitian yang digunakan yaitu penelitian kualitatif deskriptif dengan metode atau pendekatan studi kasus. Penelitian ini 
memusatkan diri secara intensif pada satu objek tertentu yang mempelajarinya sebagai suatu kasus (Creswell, 2014). Data studi kasus dapat diperoleh dari semua pihak yang bersangkutan, dengan kata lain dalam studi ini dikumpulkan dari berbagai sumber (Nawawi, 2003: 1).

Teknik pengumpulan data yang digunakan penelitian ini adalah observasi, wawancara, dan studi literatur. Peneliti akan melihat langsung ke lapangan, melakukan produksi program acara berita televisi, baik itu rapat redaksi, peliputan, penulisan, editing hingga tahap akhir berita tersebut disiarkan.

Selain itu, peneliti juga akan melakukan wawancara dengan orang-orang yang berkompeten di bidang atau berkaitan langsung dengan permasalahan yang diteliti. Adapun sumber data yang diwawancarai untuk memperoleh informasi, yaitu: (a) Manager program; (b) Produser televisi; (c) Rekan sesama reporter.

\section{HASIL DAN PEMBAHASAN}

TVOne adalah satu dari dua televisi berita nasional yang menayangkan tayangan berita 24 jam. Televisi ini berdiri tahun 2002 dengan nama Lativi. Lativi adalah televisi hiburan generic yang menayangkan program hiburan kurang lebih sama seperti stasiun televisi lain seperti film dan sinetron. Pada tahun 2008 saat stasiun televisi ini berpindah tangan ke Aburizal Bakrie, Lativi berganti nama menjadi TVOne dan mengubah citra menjadi televisi berita 24 jam. Sebagai televisi berita yang menayangkan berita 24 jam, konten program dari TVOne semuanya berisikan tayangan berita. Beragam berita yang disampaikan ini dikemas dengan berbagai jenis program seperti Talkshow, Sport, Feature, Documentary, Hard News dan Soft News. Untuk mempermudah koordinasi antar jenis program, TVOne membagi jenis-jenis program itu ke dalam beberapa divisi, yaitu Divisi Current Affair (CA), Divisi News Gathering, dan Divisi Sport.

Divisi Current Affair terdiri dari Program Talkshow, dan Program Documentary. Sedangkan Divisi News Gathering membawahi semua Program Kabar News TVOne dan Investigasi. Terakhir Divisi Sport mengatur semua program Sport di TVOne. Saat ini Program Talkshow TVOne terdapat Apa Kabar Indonesia Pagi, Apa Kabar Indonesia Malam, Fakta, Dua Sisi, Indonesia Business Forum, dan E Talk Show. Pada Program Documentary terdapat Indonesia Dalam Peristiwa, Pesona Nusantara, Indonesia Plus, Ayo Hidup Sehat, dan Auto One.

Namun yang menarik, seringkali program yang terdapat pada divisi CA tidak bertahan lama. Karena dinilai tidak dapat mendatangkan keuntungan baik dari segi share and rating maupun iklan. Setiap 6 bulan biasanya diadakan evaluasi program oleh pihak programming. Bahkan jika 
sebuah program mendapatkan share and rating yang rendah dalam kurun waktu 3 bulan berturut-turut dapat segera dicabut dalam kurun waktu yang singkat dan secepat-cepatnya.

Seperti yang diketahui bersama, share dan rating adalah hal yang sangat penting dalam tayangan program di televisi. Share dan rating yang rendah menggambarkan bahwa tayangan tidak diminati oleh penonton. Share dan rating yang rendah pun berimbas pada enggannya pengiklan memasang iklan pada tayangan tersebut. Kurangnya pengiklan membuat pemasukan televisi berkurang. Padahal biaya produksi program terus menerus dikeluarkan. Hal ini jika terus menerus terjadi dapat membuat kerugian bagi stasiun televisi. Untuk mengurangi efek domino, atau berimbas pada terganggunya biaya produksi program yang "unggulan," maka divisi programming pasti akan dengan cepat membuang program tersebut dari daftar program TVOne.

Program dokumenter juga sering tak bertahan lama. Biaya produksi program dokumenter dianggap tidak seimbang dengan hasil yang didapatkan. TVOne kemudian mulai meminimalisir tayangan dokumenter. Kalau pun masih ada tayangan dokumenter kebanyakan merupakan hasil pemutaran ulang.

Ekonomi politik media dapat terlihat dimana tak jarang program yang sebenarnya memiliki nilai berita dan jurnalistik yang bagus namun dibutuhkan untuk diberhentikan karena dianggap tidak mencapai target popularitas tayangan. Program news Kabar TVOne adalah andalan di stasiun televisi ini. Kabar News tayang 8 kali dalam sehari. Kabar Utama, 03.00, Kabar Pagi pukul 04.30, Kabar Pasar 09.30, Kabar Siang 11.00, Kabar Pasar Sore 14.00, Kabar Pilihan 14.30, Kabar Petang 17.30, dan Kabar Hari Ini 23.30. Dari jadwal penayangan terlihat bahwa Kabar News adalah keunggulan dari program TVOne. Hampir semua jam prime time dipegang oleh Kabar News. Durasi dan jadwal penayangan juga didominasi oleh Kabar News.

Dari pengamatan peneliti dan beberapa sumber menyebutkan bahwa program Kabar News lebih diutamakan untuk dijual ke pihak pengiklan. Karena program unggulan TVOne maka pihak pemasaran pun lebih mendahulukan penjualan pada program news. Dapat dikatakan program lain “dianak-tirikan" karena dianggap kurang menjual dan hanya mengisi kekosongan slot program. Hal ini diungkap oleh seorang informan anonim yang bekerja sebagai redaksi di TVOne.

"Liputan divisi kami, karena bukan news, sering dikurangi. Mungkin karena biaya produksi liputannya juga banyak, terus karena tayangan kami feature dan longlast jadi masih bisa di rerun. Sedangkan news harus jalan tiap hari. Karena namanya news, beritanya harus update. Jadi news tetap paling utama. Program non news biasanya juga ditempatkan di jam-jam yang tidak primetime. Makanya tidak jarang ratingnya rendah. 0,8 itu paling bagus kayaknya." (Wawancara J, Reporter Current Affair)

Walaupun begitu masih ada program talkshow di TVOne masih terbilang cukup diunggulkan seperti Indonesia Lawyer Club, Apa Kabar Indonesia Pagi, dan Apa Kabar Indonesia Malam. 
Ketiga program ini tergolong produktif meski tidak berada di Divisi News.ILC pada akhirnya lebih memilih pindah ke kanal digital karena dinilai lebih menguntungkan dari segi biaya produksi.

Stanley Baran (2014) mengatakan setiap kemunculan teknologi media baru mengganggu stabilitas media yang sudah ada dan memaksa dilakukannya restrukturisasi dalam skala luas dan terjadinya perubahan yang cepat. Perusahaan besar yang berbasis teknologi lama mengalami kemunduran sementara beberapa perusahaan yang baru justru memperoleh keuntungan besar.

Munculnya media sosial memang cukup membuat media arus utama kewalahan. Pasalnya tidak sedikit pengiklan lebih memilih memasang iklan di Youtube ataupun Instagram untuk memasarkan produk mereka. Selain terbilang lebih murah, pengguna media sosial juga lebih banyak dibandingkan penonton televisi pada saat ini. Teknologi komunikasi membuat penggunanya dapat mengakses informasi dimanapun dan kapanpun. Alhasil dalam kurun waktu 3 tahun ke belakang bisnis media arus utama khususnya televisi berita 24 jam mengalami kemerosotan pendapatan.

Maya May Syarah (2019) dalam artikelnya yang berjudul "Program Televisi di Era Industri 4.0" menyebutkan perkembangan media digital mulai memberikan gangguan pada bisnis utama yakni televisi. Jika dahulu iklan televisi tumbuh $15-20 \%$, saat ini mulai berkurang karena sebagian perkembangan dimakan oleh digital. Data Nielsen juga menunjukkan budget iklan digital mulai meningkat. Hal ini juga terjadi pada TVOne. Televisi ini mengalami defisit. Ditambah lagi dengan posisinya secara politik yang kontra terhadap pemerintah membuat televisi ini semakin sulit. Pengiklan berpikir dua kali untuk memasang iklan di TVOne karena jika mengiklan di media ini bisa jadi dianggap pro oposisi pemerintah.

TVOne berusaha mencari cara untuk mengembalikan kepercayaan pengiklan. Baik dengan menggunakan presenter dengan wajah oriental hingga mencoba peruntungan dengan nekad membeli tayangan Liga Indonesia. Alih alih mendapatkan keuntungan, keputusan tersebut justru membuat TVOne semakin defisit.

Begitu pula hasil temuan dari penelitian yang dilakukan Taufan Hariyadi tahun 2019.Dalam artikelnya yang berjudul "Gejolak Teve Berita di Era Konvergensi Media (Potret TVOne Dari Teve Berita ke Teve Hiburan, Kembali Ke Teve Berita Lagi)" menyebutkan pendapatan dari sektor iklan TVOne menurun seiring penurun rating dan share televisinya. Perubahan pun dilakukan, mengambil langkah mencicipi manisnya bisnis televisi hiburan. Wajah TV berita itu kemudian dihiasi beberapa sinetron drama yang memenuhi pola siaran teve berita mulai pagi hingga malam. Sejak 15 april 2017, TV berita itu resmi menayangkan lima judul sinetron drama Turki sebagai penyegaran industri televisinya, kuota jam penayangan beritanya pun dikurangi. Tujuannya meningkatkan rating dan share demi peningkatan pendapatan iklan pula.Sayangnya 
strategi menghadirkan entertainment bagi TV yang citranya melekat sebagai TV berita tak berjalan mulus. Perolehan rating dan share $T V$ tersebut terus menurun seiring serial drama Turki yang ditayangkan. Kebijakan perusahaan menghadirkan entertainment drama Turki hanya bertahan 3 bulan. Informasi yang didapat dari dalam, strategi menyuguhkan sinetron drama pada televisi berita ternyata tak mendulang pendapatan. Mulai 31 Juli 2017, televisi berita itu pun kembali ke kithah nya sebagai televisi berita. Mencari pangsa pasar penonton baru rupanya lebih sulit dibandingkan mempertahankan penonton lama. Inovasi yang dilakukan ole TVOne dengan menghadirkan film Turki, tidak dapat menaikkan rating dan share dari televisi swasta tersebut.

"Rata-rata ratingnya di bawah 1 dan share-nya di bawah 3 (persen). Share 3 persen artinya, di antara semua orang yang menonton $T V, 3$ persen diantaranya menonton program yang dimaksud. Sepekan setelah berubah format, yakni 21 dan 24 April 2017, misalnya, "Orphan Flowers" hanya memiliki share 1,9 dan 2,3. "Shehrazat" hanya 2,7 dan 2,4. Bahkan program dengan konten serius seperti "Bedah Kasus" saja bisa mendulang share hingga 3,2.Sampai di sini terlihat jelas bahwa drama Turki tak sanggup mendongkrak pundi pundi tvOne. Ia terpaksa kembali ke konsep TV berita. Dan keputusan itu diambil cepat. Juli 2017 atau hanya 3 bulan sejak berubah format, tvOne menghentikan penayangan serial Turki dengan alasan "season break" atau jeda tayang di sela musim. Satu musim biasanya 13 episode. Lalu sekejap kemudian, 31 Juli 2017, tvOne kembali menjadi TV berita."

Pada akhirnya semacam ada keharusan bagi media konvensional untuk melakukan konvergensi media ketimbang hanya bermanuver pada sisi konten yang dijual di layar televisinya saja. Karena berbicara konvergensi tidak hanya fokus pada konten tetapi juga memberi perhatian pada distribusi konten tersebut. Bagaimana konten produksi televisi berita bisa sampai kepada khalayak dalam waktu cepat melalui berbagai platform secara online atau digital. Integrasi dalam konvergensi media ini melahirkan kemampuan media massa dalam menyampaikan konten informasi atau berita yang lebih cepat, beragam dan dinamis. Artinya media televisi konvensional harus menggunakan platform internet untuk mempertahankan bisnis mereka, sekaligus tidak kehilangan penontonnya. Dengan demikian, media televisi tidak kehilangan pemasukan dari iklan meski era new media kini menjadi ancaman. (Taufan, 2019)

Cara berikutnya yang digunakan adalah dengan mengadopsi konten media sosial ke dalam paket beritanya.Program news menjadi andalan di TVOne dan masuk akal jika redaksi mencoba cara menghadirkan segmen viral dalam Kabar TVOne. Salah satu contoh berita viral yang diangkat baru-baru ini adalah kontroversi KKN Desa Penari. Ini muncul di semua berita Kabar News bahkan di program talkshow AKI Pagi.

Proses produksi program berita yang mengangkat tema video yang viral sebenarnya hampir sama dengan proses produksi berita yang lain. Hanya saja untuk video viral, tugas reporter 
adalah melakukan verifikasi ke lokasi kejadian lalu mewawancarai para ahli dan laporan langsung dari tempat kejadian.

"Biasanya yang memilih tema adalah produser dan asisten produser. Disetujui oleh produser eksekutif dan manager program. Bahkan jika isu berkaitan dengan isu sensitif, bisa dibicarakan hingga wakil pimpinan redaksi, dan pimpinan redaksi. Hasil liputan reporter tetap yang lebih utama. Kalau berita viral itu ada videonya, kalau bagus dan eksklusif, akan jadi gambar berita. Nanti akan ditambah dengan gambar yang direkam oleh kameramen TVOne. Dan biasanya kalau beritanya punya nilai berita banget, seringnya disuruh live dari tempat kejadian." (Wawancara DS-Reporter News)

Salah satu contoh berita viral yang sempat diangkat oleh TVOne terkait kontroversi KKN Desa Penari.Peneliti sempat mewawancarai produser Apa Kabar Indonesia Pagi tentang alasan mengangkat tema tersebut ke dalam program mereka. Cerita horor yang masih penuh teka teki itu dinilai mampu membuat publik penasaran dengan lokasi tempat kejadian di cerita yang entah fiktif maupun fakta. Daya tarik tersebut dinilai mampu membuat penonton bertahan melihat program AKI Pagi dengan tema KKN Desa Penari. Usulan tema itu diterima oleh produser eksekutif hingga ke taraf manager. Alhasil tema KKN Desa Penari mengisi satu segmen AKI Pagi pada hari Rabu tanggal 4 September 2019.

Isu tersebut terus bergulir. Produser ingin menaikkan kembali tema KKN Desa Penari. Namun sayang, ditentang oleh manajer yang beranggapan bahwa tidak semua hal viral harus dinaikkan dan diikuti sampai tuntas. Apalagi tidak berhubungan dengan kepentingan orang banyak dan lebih ke arah mistis. Akhirnya, tema KKN Desa Penari hanya dinaikkan satu kali dengan hasil share and rating 0,4/4.6. Sebuah hasil akhir yang standar dan nilai yang biasa didapat untuk tema-tema lain yang tidak viral. Dapat disimpulkan bahwa viral atau tidaknya sebuah tema tidak berbanding lurus dengan hasil share and rating yang dihasilkan.Berbicara tentang video viral Kabar News TVOne bahkan sempat menyediakan segmen tersendiri untuk pemutarannya. Setelah akhirnya dihapuskan karena terjadi pro dan kontra antara pengambil kebijakan program. Namun pengambilan konten viral masih tetap dilakukan meskipun tidak berdiri dalam satu segmen tersendiri.

Ada beberapa alasan segmen video viral dihapuskan dalam Kabar News TVOne. Selain tidak terlalu berpengaruh pada share and rating, juga tidak berpengaruh pada pemasangan iklan. Bahkan cukup beresiko untuk digunakan karena video yang viral di media sosial tidak diambil oleh jurnalis profesional. Terkadang video tersebut tidak memenuhi kriteria dasar jurnalistik. Ini dapat berdampak pada kredibilitas media jika menampilkan video yang tidak jelas kebenaran beritanya seperti kasus Audrey yang viral dan sempat mengecoh media arus utama. Awalnya muncul video viral seorang siswi SMP di Pontianak yang dikeroyok 12 anak SMA karena 
sepupunya dituduh merebut kekasih salah satu tersangka pengeroyokan. Siswi SMP yang kemudian diketahui bernama Audrey itu akhirnya terluka parah dan dikabarkan mengalami depresi yang berat. Kasus ini mendapatkan perhatian bahkan hingga ke presiden Republik Indonesia Joko Widodo. Namun ternyata ada banyak kebohongan yang dilakukan Audrey mulai dari penyebab pertikaian yang sebenarnya berawal dari kata kasar yang diucapkan Audrey sehingga menyakiti hati si pelaku. Hingga kondisi Audrey yang dikabarkan depresi berat, namun masih sempat menuliskan komentar di kolom Instagram untuk meminta didukung oleh Atta Halilintar. Publik kecewa dengan kebenaran yang terungkap. Media pun merasa bersalah karena telah menyebarkan berita tentang Audrey termasuk TVOne.

Sejak kasus Audrey TVOne mulai berhati-hati untuk menyiarkan berita yang tengah viral. Hal ini dilakukan untuk menjaga kredibilitas media. Kemerosotan kredibilitas akan berakibat pada menurunkan pengiklan di media tersebut. Kejadian ini sudah terbukti pasca pemilihan umum 2014 dimana hasil perhitungan cepat TVOne berbeda dengan media lainnya. Sejenak, TVOne mulai diragukan kebenaran beritanya. Pengiklan pun pergi berhamburan mencari media televisi yang lebih mereka percaya.TVOne juga tidak akan mengangkat tema yang dianggap tidak sesuai dengan "jati dirinya”. Seperti berita Ustad Abdul Somad yang menistakan salib dan patung Yesus. Berita ini viral setelah beredar video ceramah Ustad Abdul Somad yang mengatakan salib didiami oleh jin kafir karena patung yang tergantung di situ. TVOne tidak mengangkatnya karena dinilai dapat memecah persatuan dan kesatuan. Isu SARA memang sangat riskan untuk diangkat ke layar kaca. Selain itu, TVOne tidak mengangkat tema tersebut karena adanya kedekatan hubungan dengan ustad Abdul Somad. Ustadz Abdul Somad kerap mengisi pengajian dalam program dakwah di TVOne. Selain itu, TVOne juga memiliki citra yang baik di mata para pecinta ustadz Abdul Somad. Alhasil, TVOne lebih memilih tidak untuk mengangkat isu tersebut baik dalam berita news maupun talkshownya.

Selain dalam program news, program non-berita seperti Current Affair dan Sport di TVOne juga kerap mengangkat tayangan viral dari media sosial. Di Current Affair bahkan terdapat program yang berisi kumpulan berita viral berjudul "Spektakuler." Dikutip dari situs tvonenews.com, disebutkan bahwa Spektakuler merupakan program majalah berita atau news magazine yang menyuguhkan fenomena unik di berbagai belahan dunia. Setiap episodenya diisi dengan tema yang beragam seperti cerita inspiratif, langka, unik, misteri, informatif dan menghibur. Tema-tema tersebut akan dirangkum dan kompilasi menjadi 5 yang ter-unik, ter-viral, ter-fenomenal dan lain-lain.

Program Spektakuler sarat akan informasi tetapi dikemas dengan sangat ringan dan menghibur. Spektakuler tampil dengan visual dan alur yang menarik sehingga pemirsa tidak 
merasa jenuh mengikuti informasi yang diberikan. Spektakuler hadir dengan durasi 30 menit tayang setiap Senin - Jumat pukul 13.00 WIB.

Meski sudah mengangkat berita viral dari media sosial, tidak membuat program Spektakuler memperoleh share dan rating yang tinggi. Hal ini terlihat dari share dan rating yang dikeluarkan Nielsen pada tanggal 19 Agustus 2021 dan 20 Agustus 2020.Dari gambar di atas terlihat bahwa program Spektakuler tidak mendapatkan rating yang baik dibandingkan program lainnya. Tayangan Apa Kabar Indonesia Pagi, Rumah Mamah Dedeh, Kabar Arena, Sidik Jari, dan Kabar Siang bisa mendapat rating yang tinggi dibandingkan program Spektakuler, meskipun yang tidak mengangkat berita viral. Dengan demikian, penayangan berita viral di program berita televisi, tidak menjamin program tersebut akan mendapat perhatian dari penonton.

\section{PENUTUP}

Berdasarkan penjelasannya dari bab sebelumnya, dapat disimpulkan bahwa seluruh strategi ekonomi politik yang dimainkan oleh sebuah media merupakan sebuah cara yang dilakukan untuk menghidupkan media tersebut sehingga dapat memiliki umur yang panjang. Termasuk yang dilakukan TVOne. Mulai dari menyeleksi tema yang dianggap tidak menjual, menghapus program yang dianggap tidak menguntungkan, hingga mencoba menarik perhatian penonton dengan memasukkan konten viral ke dalam tayangannya.

Kemudian dapat dikatakan bahwa tidak selamanya hal yang viral di media sosial, dapat viral juga di media arus utama. Media arus utama hanya berfungsi untuk menguatkan bahwa sebuah berita itu penting untuk dibahas. Untuk masalah kecepatan akses dan mobilitas, media sosial dan media online masih menjadi andalan bagi masyarakat untuk mendapatkan informasi real time.

Selain itu, dalam proses produksi program berita di televisi, meski yang memegang peranan penting untuk menentukan naik atau tidaknya sebuah berita adalah para gatekeeper, namun respon penonton juga menentukan keberlangsungan berita tersebut untuk kembali didalami atau tidak.

Kemudian jika sebuah media berada di oposisi pemerintah, pengiklan cenderung menjauh. Sehingga dapat mengurangi pemasukan bisnis media. Ini dapat didalami lagi, mengenai apa hal yang mendasari pengiklan menjauh ke media oposisi pemerintah. Padahal menurut peneliti jika media oposisi pemerintah, namun penontonnya banyak, tentu masih tetap menguntungkan bagi para pengiklan.

Media juga cenderung berusaha tidak mengangkat berita tentang tokoh yang berafiliasi dengan mereka. Hal ini tentu dilakukan untuk menjaga hubungan dan kepentingan lain dari para petinggi media. Seperti yang diketahui, tidak ada media televisi di Indonesia yang independen. 
Semuanya memiliki afiliasi baik itu secara ekonomi maupun politik.

Dari penelitian juga diketahui bahwa setiap berita viral harus dilakukan verifikasi lebih mendalami untuk tetap menjaga kredibilitas media. Ini sangat penting mengingat banyak video viral di media sosial yang tidak lengkap. Kembali ke pengetahuan dasar bahwa video yang ada di media sosial dibuat oleh warga biasa yang belum tentu memiliki dasar jurnalistik. Dan tidak tahu apa maksud di balik pembuatan video tersebut. Sedangkan media arus utama, memiliki tanggung jawab besar terhadap informasi yang disampaikan agar tidak ada pihak yang dirugikan.

Kemunculan media sosial membuat pengiklan jarang memasang iklan mereka di televisi. Mengangkat video viral di media sosial dianggap ampuh untuk menaikkan pengiklan. Namun sayangnya, share dan rating video viral yang ditayangkan tidak berbanding lurus dengan keviralannya di media sosial.

\section{DAFTAR PUSTAKA}

Baran, Stanley J \& Davis Dennis, K. 2010. Teori Komunikasi Massa: Dasar, Pergolakan, dan Masa Depan, Jakarta: Salemba Humanika.

Creswell, J. W. (2014). Research Design (4th ed.). London: Sage Publications, Inc.

Giddens, A. (2006). Sociology (5th ed.). Cambridge: Polity Press.

Hariyadi, Taufan. 2019. Gejolak Teve Berita di Era Konvergensi Media (Potret TVOne Dari Teve Berita ke Teve Hiburan, Kembali Ke Teve Berita Lagi. Jakarta : BSI

Maxwell, R., \& Miller, T. (2011). Old, New and Middle-Aged Media Convergence. Cultural Studies, 25(4-5), 585-603. https://doi.org/10.1080/09502386.2011.600550

McQuail, Denis. 2011. Teori Komunikasi Massa.. Jakarta: Salemba Humanika.

Mosco, Vincent. 2009. The Political Economy of Communication. London: Sage

Muchtar, N., \& Ritchey, J. A. (2014). Preaching, community, and convergence : Use of old and new media by progressive Indonesian Islamic leaders. The International Communication Gazette, 76(4-5), 60-376. https://doi.org/10.1177/1748048514524099

Murschetz, P. (2015). Connected television: Media Convergence, Industry Structure, and Corporate Strategies. Annals of the International Communication Association, 40(1), 69-93. https://doi.org/10.1080/23808985.2015.11735256

Sapiro, V., \& Soss, J. O. E. (2010). Spectacular Politics, Dramatic Interpretations : Multiple Meanings in the Thomas / Hill Hearings. Political Communication, 16(3), 37-41. https://doi.org/10.1080/105846099198640

Sen, K., \& Hill, D. T. (2006). Media, Culture, and Politics in Indonesia. Jakarta: Equinox Publishing. 
Sullivan, D., \& Jiang, Y. (2010). Media Convergence and the Impact of the Internet on the M \& A Activity of Large Media Companies. Journal of Media Business Studies, 7(4), 21-40. https://doi.org/10.1080/16522354.2010.11073513

Syarah, Maya May. 2019. Program Televisi di Era Industri 4.0. Jakarta: BSI

Tapsell, R. (2019). Kuasa media di Indonesia: kaum oligarki, warga, dan revolusi digital. Tangerang: Marjin Kiri.

Wilson, T. (2000). Media Convergence: Watching Television, Anticipating Going On-Line. Media Asia, 27(1), 3-9. https://doi.org/10.1080/01296612.2000.11771935 